\begin{tabular}{lccr} 
A R C H I V E & O F & M E C H A N I C A L & E N G I N E E R I N G \\
\hline VOL. LX & 2013 & Number 4 \\
10.2478/meceng-2013-0032 \\
Key words: modelling, vertical mixed-flow pump, numerical analysis
\end{tabular}

HENRYK HOLKA*, TOMASZ JARZYNA *

\title{
MODELLING OF VERTICAL SHAFT OF MIXED-FLOW PUMP
}

\begin{abstract}
The aim of the work was modelling of shaft and calculation of natural vibration frequencies and critical rotations of a large-size, vertical mixed flow pump of total length $\mathrm{l}=4866 \mathrm{~mm}$. Equations of motion were determined analytically, and then calculation results were verified by numerical modelling. The difficulty of the problem consisted in the shaft bearing, in which four hydrodynamic bearings of unknown parameters were applied. A four-mass beam supported on flexible supports of rigidity $\mathrm{k}$ and damping $\mathrm{c}$ was assumed as the discrete model of the shaft. Equations of motion for the system were derived with the method of forces. In order to verify correctness of the derived equations, one considered three models of the beam with different support configuration: the beam supported on rigid supports, the beam supported on elastic supports, and the beam supported on flexible supports of rigidity $\mathrm{k}$ and damping c. Calculation results are presented in tables and graphs.
\end{abstract}

\section{Introduction}

One of the most important tasks associated with dynamics of fluid-flow machines is determination of frequencies of free vibrations and critical rotations of the shaft. In the presented paper, we analyse the shaft of a largesize, 6-metre long mixed-flow pump. The dynamic analysis was a difficult task due to the lack of data on rigidity and damping of shaft supports. The available data were constructional drawings and measurements of vibrations of the body taken during machine operation and during its coasting. The analysis of shaft vibrations was conducted with an analytical method, which offered certain advantages over commonly-used numerical methods. Because of complexity of the object [1], correctness of the analysis was verified with a numerical method.

* Faculty of Mechanical Engineering, University of Technology and Life Sciences, ul. Prof. S. Kaliskiego 7, 85-796 Bydgoszcz, Poland; E-mail: holka@utp.edu.pl; tomasz.jarzyna@utp.edu.pl 
The starting point for calculations was a structural model constructed according to the requirements of similarity to the real object, taking into account the tasks to be solved, and ensuring the possibility and easiness of solving the equations $[2,3]$. The equations of motion were defined in the next step. In this work, because of model complexity, we applied the method of forces, commonly used in dynamics of constructions.

The basic characteristic data of the unit are as follows:

- efficiency:

$$
5000 \mathrm{~m}^{3} \cdot \mathrm{h}^{-1},
$$

- lifting height:

$60 \mathrm{mH}_{2} \mathrm{O}$,

- engine power:

$1250 \mathrm{~kW}$,

- rotating speed:

$740 \mathrm{rpm}$,

- total height of unit:

$9,8 \mathrm{~m}$.

Overall dimensions of the unit influence the manner the unit is seated on the foundation. The basic assemblies of the unit are: the electric engine, founded on the upper foundation (Fig. 1) and the main pump supported by the lower foundation. The spatial model of the whole pump is presented in Figure 2.

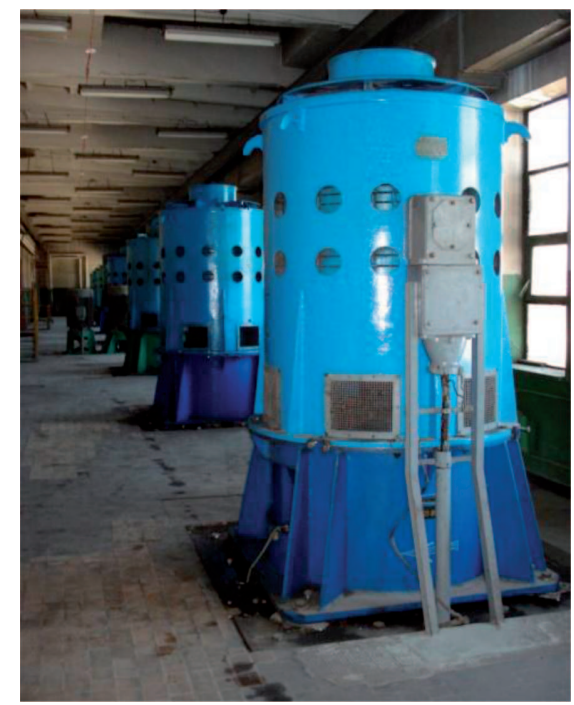

Fig. 1. Electric engine of the pump

\section{Measurement results, determine rigidity and damping of supports}

Measurements of pump vibrations were carried out at eight measuring points, located at different heights on the pump (Fig. 3). The vibrations were 


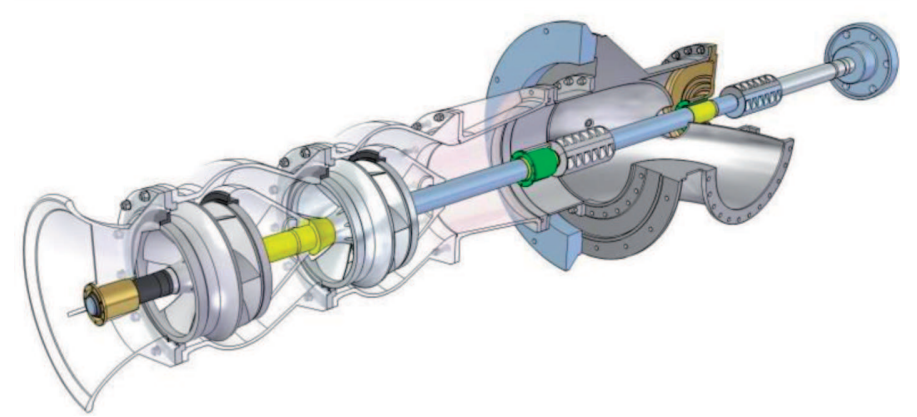

Fig. 2. View of vertical mixed-flow pump

measured in three directions. Measurement results of vibrations speed are presented in Table 1.

Table 1.

Vibration measurement results

\begin{tabular}{|c|c|c|c|c|c|c|}
\hline \multirow{2}{*}{} & \multicolumn{6}{|c|}{ Direction and value of vibration component } \\
\cline { 2 - 7 } & \multicolumn{2}{|c|}{$\mathrm{x}$} & \multicolumn{2}{|c|}{$\mathrm{y}$} & \multicolumn{2}{c|}{$\mathrm{z}$} \\
\cline { 2 - 7 }$\left[\begin{array}{c}\text { Speed } \\
{[\mathrm{mm} / \mathrm{s}]}\end{array}\right.$ & $\begin{array}{c}\text { Acceleration } \\
{\left[\mathrm{m} / \mathrm{s}^{2}\right]}\end{array}$ & $\begin{array}{c}\text { Speed } \\
{[\mathrm{mm} / \mathrm{s}]}\end{array}$ & $\begin{array}{c}\text { Acceleration } \\
{\left[\mathrm{m} / \mathrm{s}^{2}\right]}\end{array}$ & $\begin{array}{c}\text { Speed } \\
{[\mathrm{mm} / \mathrm{s}]}\end{array}$ & $\begin{array}{c}\text { Acceleration } \\
{\left[\mathrm{m} / \mathrm{s}^{2}\right]}\end{array}$ \\
\hline 1 & 4.0108 & 1.2332 & 5.5884 & 1.8884 & - & - \\
\hline 2 & 5.0412 & 1.3568 & 5.158 & 1.6092 & - & - \\
\hline 3 & 1.394 & 1.2896 & 1.5112 & 1.7412 & - & - \\
\hline 4 & 1.276 & 0.61 & 1.1312 & 0.7532 & - & - \\
\hline 5 & - & - & - & - & 2.2176 & 0.7012 \\
\hline 6 & 0.6392 & 0.7288 & 1.3912 & 0.6996 & - & - \\
\hline 7 & 1.1968 & 0.4456 & 0.7972 & 0.7984 & - & - \\
\hline 8 & - & - & - & - & 0.4552 & 0.5628 \\
\hline
\end{tabular}

Measurement results showed that, at points 1 and 2, the speeds of vibrations admissible for this type of machinery were exceeded and, according to the Polish Norm, the machine was only conditionally admitted for operation. It was necessary to explain the reason for such a high level of vibrations, hence the need of the hereby analysis. In further part of initial tests, we performed recording of pump vibrations during its start-up (Figure 4).

Recording of vibrations during coasting reviled only one harmonic component corresponding to the rotational speed of the pump shaft.

The last stage of initial tests, allowing for solving the discrete model of the shaft, was to determine unknown parameters of shaft's supports i.e. rigidity and damping. Particularly difficult was determination of damping 


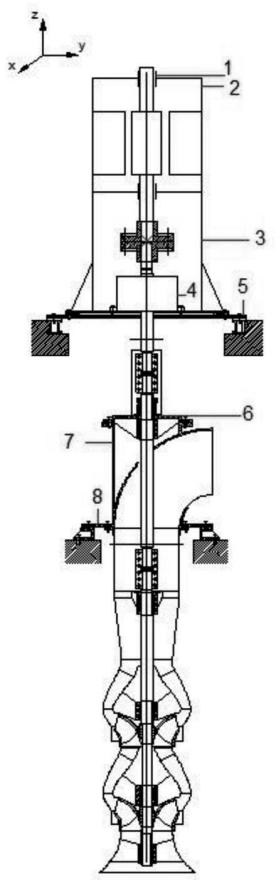

Fig. 3. Vibration measuring points

\section{$v\left[\mathrm{~m} / \mathrm{s}^{2}\right]$}

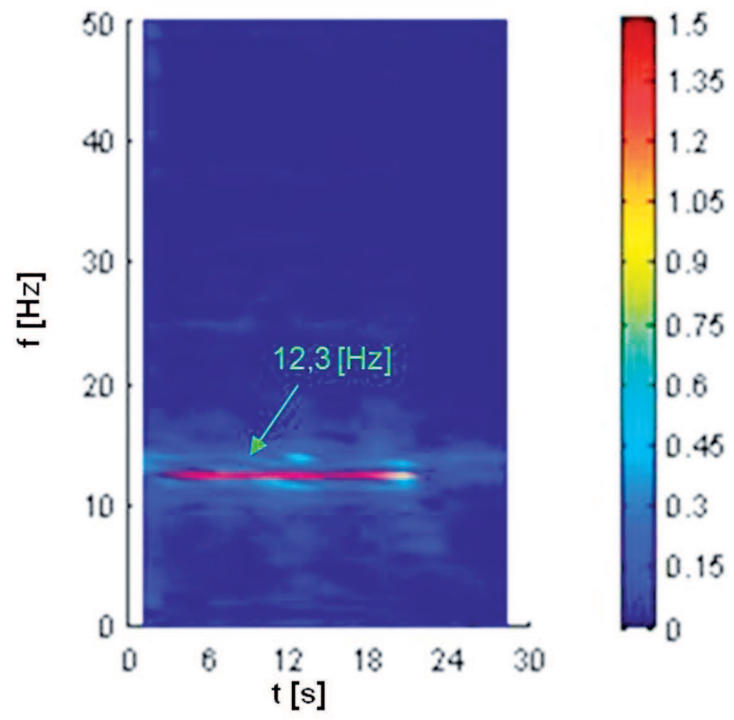

Fig. 4. Course of vibration speed during pump coasting 
in hydrodynamic bearings. Deriving of such a parameter on the grounds of theoretical analyses would be a very complex task. Thus we decided to determine damping on the basis of experimental tests. In order to do so, a testing position was constructed (Figure 5) for simulating the real system.

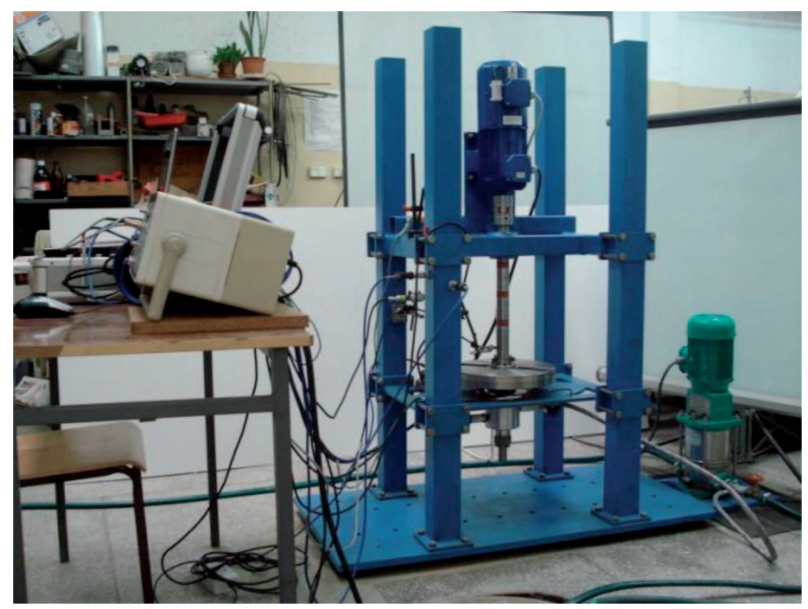

Fig. 5. Testing position for measuring course of vibrations speed during pump coasting

On the basis of experimental tests, the following values of rigidity and damping parameters were assumed: $\mathrm{k}=7370746 \mathrm{~N} / \mathrm{m}, \mathrm{c}=1223436 \mathrm{Ns} / \mathrm{m}$.

\section{Structural model}

For calculation of natural frequencies, we applied a discrete model. Numerous examples of shaft calculations show that the results obtained when using such models do not significantly differ from those acquired with methods based on distributed mass models. In other words, spatial distribution of mass of the rotating shaft has a minor influence on its critical rotational velocity $[2,4]$.

Figure 6 presents subsequent stages of simplification of the pump's physical model up to the form of a discrete model. The aforementioned model neglects the gyrostatic moment of the two rotors, as they have a compact structure and low length-to-diameter ratio, $1 / \mathrm{d}$.

As it can be seen in Fig. 6, the shaft consists of four discrete masses supported flexibly at four points of parameters $\mathrm{k}_{i}$ and $\mathrm{c}_{i}$. The values of individual masses were calculated with the Rayleigh energy method.

Calculations for the model from Figure $6 \mathrm{c}$ were performed for the following three variants (variant III is presented separately in Figure 7).

Variant I - shaft supported on rigid supports

Data: $\mathrm{m}_{1}=600,6 \mathrm{~kg}, \mathrm{~m}_{2}=408,02 \mathrm{~kg}, \mathrm{~m}_{3}=35,55 \mathrm{~kg}, \mathrm{~m}_{4}=83,98 \mathrm{~kg}$. 
a)

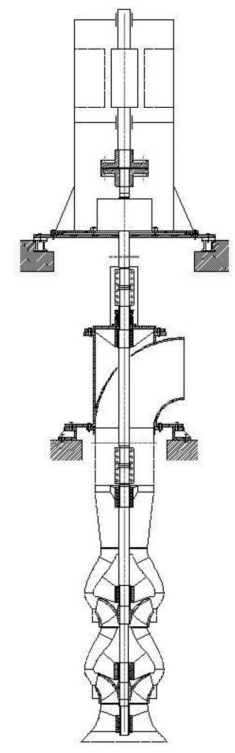

b)

c)

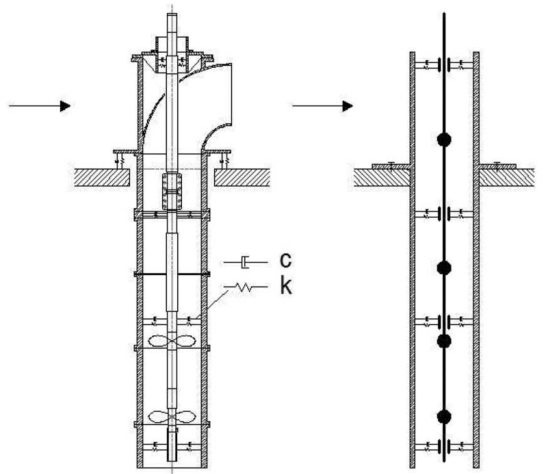

Fig. 6. Subsequent stages of model simplification

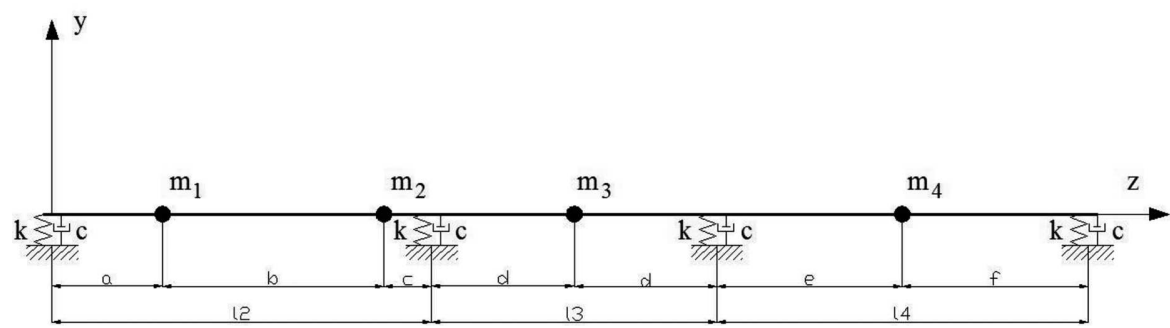

Fig. 7. Discrete model of shaft, $\mathrm{m}_{i}[\mathrm{~kg}], \mathrm{k}\left[\mathrm{N} \cdot \mathrm{m}^{-1}\right], \mathrm{c}\left[\mathrm{Ns} \cdot \mathrm{m}^{-1}\right]$

Variant II - shaft supported on elastic supports

Data: mass as in variant $\mathrm{I}, \mathrm{k}_{1}=\mathrm{k}_{2}=\mathrm{k}_{3}=\mathrm{k}_{4}=7370746 \mathrm{~N} / \mathrm{m}$.

Variant III - shaft supported on supports of rigidity $\mathrm{k}_{i}$ and damping $\mathrm{c}_{i}$

Data: mass $\mathrm{m}$, rigidity $\mathrm{k}$ as in variant I and II, damping $\mathrm{c}_{1}=\mathrm{c}_{2}=\mathrm{c}_{3}=\mathrm{c}_{4}=$ $1223436 \mathrm{Ns} / \mathrm{m}$.

\section{Equations of motion and their solutions}

Based on the structural model, we derived the equations of motion. Taking into account complexity of the model, we selected the method of forces from among several other known methods. In this method, one applies the so-called influence coefficients $\delta_{i j}$, calculated with methods known from statistics. The physical sense of the coefficient $\delta_{i j}$ is the displacement of i-th 
cross-section caused by a generalized unitary force applied to $\mathrm{j}$-th crosssection.

$$
\begin{aligned}
& \delta_{11} m_{1} \ddot{y}_{1}+\delta_{12} m_{2} \ddot{y}_{2}+\delta_{13} m_{3} \ddot{y}_{3}+\delta_{14} m_{4} \ddot{y}_{4}+y_{1}=0 \\
& \delta_{21} m_{1} \ddot{y}_{1}+\delta_{22} m_{2} \ddot{y}_{2}+\delta_{23} m_{3} \ddot{y}_{3}+\delta_{24} m_{4} \ddot{y}_{4}+y_{2}=0 \\
& \delta_{31} m_{1} \ddot{y}_{1}+\delta_{32} m_{2} \ddot{y}_{2}+\delta_{33} m_{3} \ddot{y}_{3}+\delta_{34} m_{4} \ddot{y}_{4}+y_{3}=0 \\
& \delta_{41} m_{1} \ddot{y}_{1}+\delta_{42} m_{2} \ddot{y}_{2}+\delta_{43} m_{3} \ddot{y}_{3}+\delta_{44} m_{4} \ddot{y}_{4}+y_{4}=0 .
\end{aligned}
$$

After substituting the expected solutions $\mathrm{y}_{i}=\mathrm{a}_{i} \cdot \sin \omega$ t into equations (4.1), we obtain the characteristic determinant, from which eigenfrequencies of the system can be derived:

$$
\left|\begin{array}{cccc}
\delta_{11} m_{1} \omega^{2}-1 & \delta_{12} m_{2} \omega^{2} & \delta_{13} m_{3} \omega^{2} & \delta_{14} m_{4} \omega^{2} \\
\delta_{21} m_{1} \omega^{2} & \delta_{22} m_{2} \omega^{2}-1 & \delta_{23} m_{3} \omega^{2} & \delta_{24} m_{4} \omega^{2} \\
\delta_{31} m_{1} \omega^{2} & \delta_{32} m_{2} \omega^{2} & \delta_{33} m_{3} \omega^{2}-1 & \delta_{34} m_{4} \omega^{2} \\
\delta_{41} m_{1} \omega^{2} & \delta_{42} m_{2} \omega^{2} & \delta_{43} m_{3} \omega^{2} & \delta_{44} m_{4} \omega^{2}-1
\end{array}\right|=0 .
$$

Solving (4.2), we obtain the frequency equation:

$$
A \cdot \omega^{8}+B \cdot \omega^{6}+C \cdot \omega^{4}+D \cdot \omega^{2}+1=0
$$

where the constants A, B, C and D are calculated from (4.2). For example, $\mathrm{A}$ and $\mathrm{B}$ have the form:

$$
\begin{aligned}
& A=\left(\delta_{11} \delta_{22} \delta_{33} \delta_{44}+2 \delta_{11} \delta_{23} \delta_{24} \delta_{34}+\right. \\
& 2 \delta_{22} \delta_{13} \delta_{14} \delta_{34}+2 \delta_{33} \delta_{12} \delta_{14} \delta_{24}+2 \delta_{44} \delta_{12} \delta_{13} \delta_{23}-2 \delta_{12} \delta_{14} \delta_{23} \delta_{34}-2 \delta_{12} \delta_{13} \delta_{24} \delta_{34}- \\
& 2 \delta_{13} \delta_{14} \delta_{23} \delta_{24}-\delta_{12}^{2} \delta_{33} \delta_{44}+\delta_{13}^{2} \delta_{22} \delta_{44}-\delta_{14}^{2} \delta_{22} \delta_{33}-\delta_{23}^{2} \delta_{11} \delta_{44}-\delta_{24}^{2} \delta_{11} \delta_{33}- \\
& \left.\delta_{34}^{2} \delta_{11} \delta_{22}+\delta_{12}^{2} \delta_{34}^{2}+\delta_{13}^{2} \delta_{24}^{2}+\delta_{14}^{2} \delta_{23}^{2}\right) m_{1} m_{2} m_{3} m_{4} \\
& B=\left(-\delta_{11} \delta_{22} \delta_{33}+\delta_{11} \delta_{23}^{2}+\delta_{33} \delta_{12}^{2}+\delta_{22} \delta_{13}^{2}-2 \delta_{12} \delta_{13} \delta_{23}\right) m_{1} m_{2} m_{3}+ \\
& \left(-\delta_{11} \delta_{22} \delta_{44}+\delta_{11} \delta_{24}^{2}+\delta_{44} \delta_{12}^{2}+\delta_{22} \delta_{14}^{2}-2 \delta_{12} \delta_{14} \delta_{24}\right) m_{1} m_{2} m_{4}+\left(-\delta_{11} \delta_{33} \delta_{44}+\right. \\
& \left.\delta_{11} \delta_{34}^{2}+\delta_{44} \delta_{13}^{2}+\delta_{33} \delta_{14}^{2}-2 \delta_{13} \delta_{14} \delta_{34}\right) m_{1} m_{3} m_{4}+ \\
& \left(-\delta_{22} \delta_{33} \delta_{44}+\delta_{33} \delta_{24}^{2}+\delta_{44} \delta_{23}^{2}+\delta_{22} \delta_{34}^{2}-2 \delta_{23} \delta_{24} \delta_{34}\right) m_{2} m_{3} m_{4} .
\end{aligned}
$$

Calculation of the Maxwell influence coefficients in equations (4.1) and (4.2) is very time-consuming. The form of coefficients $\delta_{11}, \delta_{12}$ and $\delta_{13}$ is presented hereunder: 


$$
\begin{aligned}
& \delta_{11}=\frac{1}{E I}\left\{\frac{b+c}{l_{2}}\left[1+\frac{a}{2 l_{2}^{2}} \cdot \frac{12\left(l_{3}+l_{4}\right)}{l_{3}} \cdot\left(\frac{2}{3} a^{2}+(b+c)\left(a+\frac{1}{3} b+\frac{1}{3} c\right)\right) \frac{l_{3}}{l_{3}^{2}-4\left(l_{2}+l_{3}\right)\left(l_{3}+l_{4}\right)}\right] .\right. \\
& \left.\frac{a}{6}\left(l_{2}^{2}-a^{2}\right)-\frac{\left(l_{2}-a\right)^{3}}{6 l_{2}} a\right\}, \\
& \delta_{12}=\frac{1}{E I}\left\{\frac{b+c}{l_{2}}\left[1+\frac{a}{2 l_{2}^{2}} \cdot \frac{12\left(l_{3}+l_{4}\right)}{l_{3}} \cdot\left(\frac{2}{3} a^{2}+(b+c)\left(a+\frac{1}{3} b+\frac{1}{3} c\right)\right) \frac{l_{3}}{l_{3}^{2}-4\left(l_{2}+l_{3}\right)\left(l_{3}+l_{4}\right)}\right] .\right. \\
& \frac{a+b}{6}\left(l_{2}^{2}-(a+b)^{2}\right)+\frac{1}{6}\left(b^{3}-\frac{\left(l_{2}-a\right)^{3}}{l_{2}}(a+b)\right\}, \\
& \delta_{13}=\frac{1}{E I}\left\{\left[-\frac{3 d^{3}}{l_{2} l_{3}^{2}}-\frac{2\left(l_{3}+l_{4}\right)}{l_{2} l_{3}} \cdot\left[\frac{3}{2} d^{2} \cdot\left(\frac{2\left(l_{2}+l_{3}\right)}{l_{3}}-1\right) \cdot \frac{l_{3}}{l_{3}^{2}-4\left(l_{3}+l_{4}\right)\left(l_{2}+l_{3}\right)}\right]\right] \cdot\left[\frac{l_{2}^{2}}{6} a-\frac{a^{3}}{6}\right]\right\} .
\end{aligned}
$$

It is obvious that $\delta_{i j}=\delta_{j i}$.

After substituting numerical data into Eq. $4.5(\mathrm{a}=518.12 \mathrm{~mm}, \mathrm{~b}=1039.85$ $\mathrm{mm}, \mathrm{c}=225.03 \mathrm{~mm}, \mathrm{~d}=670 \mathrm{~mm}, \mathrm{e}=\mathrm{f}=871.6 \mathrm{~mm}, \mathrm{l}_{2}=1783 \mathrm{~mm}, \mathrm{l}_{3}=1340$ $\mathrm{mm}, 1_{4}=1743.2 \mathrm{~mm}, \mathrm{I}=8290663 \mathrm{~mm}^{4}$ and $\left.\mathrm{E}=206000 \mathrm{MPa}\right)$, one can determine values of the influence coefficients (Table 2).

Table 2.

Influence coefficients values, variant I

\begin{tabular}{|c|c|}
\hline$\delta_{\mathbf{i j}}$ & Result $[\mathbf{m} / \mathbf{N}]$ \\
\hline$\delta_{11}$ & $3.52908 \mathrm{E}-08$ \\
\hline$\delta_{12}=\delta_{21}$ & $9.14495 \mathrm{E}-09$ \\
\hline$\delta_{13}=\delta_{31}$ & $-7.30507 \mathrm{E}-09$ \\
\hline$\delta_{14}=\delta_{41}$ & $3.43234 \mathrm{E}-09$ \\
\hline$\delta_{22}$ & $6.38219 \mathrm{E}-09$ \\
\hline$\delta_{23}=\delta_{32}$ & $-5.67385 \mathrm{E}-09$ \\
\hline$\delta_{24}=\delta_{42}$ & $2.6659 \mathrm{E}-09$ \\
\hline$\delta_{33}$ & $1.76234 \mathrm{E}-08$ \\
\hline$\delta_{34}=\delta_{43}$ & $-1.00043 \mathrm{E}-08$ \\
\hline$\delta_{44}$ & $4.30617 \mathrm{E}-08$ \\
\hline
\end{tabular}

Finally, after substituting all the data into Eq. 4.3, we obtain $3,235 \cdot 10^{-23} \cdot \omega^{8}-1,209 \cdot 10^{-17} \cdot \omega^{6}+9,43 \cdot 10^{-11} \omega^{4}-2,098 \cdot 10^{-0,5} \cdot \omega^{2}+1=0$.

After calculations, we determine all roots of the polynomial (4.6):

$\mathrm{f}_{1}=40.63 \mathrm{~Hz}, \mathrm{f}_{2}=82.67 \mathrm{~Hz}, \mathrm{f}_{3}=126.84 \mathrm{~Hz}$, and $\mathrm{f}_{4}=264.73 \mathrm{~Hz}$. 


\section{Variant II}

The equations of motion, similarly as in variant I, have the form of (4.1). Because the shaft's support is elastic in this variant, the coefficients $\delta_{i j}$ should be calculated in a different way. We applied the Maxwell-Mohr formula, which takes into account not only the action of forces, but also thermal influences, elasticity of joints and the influence of non-elastic displacements on the system deformation [5]. For the considered example, the formula takes the form of:

$$
\delta_{i a}^{\prime}=\sum \int_{s} \frac{M_{i} M_{a}}{E I} d s+\sum \frac{R_{i} R_{a}}{k},
$$

where:

$\delta^{\prime}{ }_{i a}$ - displacement of basic system at point $\mathrm{i}$ under unitary force applied to point a $[\mathrm{m} / \mathrm{N}]$,

$\mathbf{M}_{i}, \mathbf{M}_{a}$ - bending moments caused by actions of unitary forces applied at points $\mathrm{i}$ and $\mathrm{a}[\mathrm{m}]$,

$\mathrm{R}_{i}, \mathrm{R}_{a}$ - reactions of joints to loads of unitary forces applied at points $\mathrm{i}$ and a $[\mathrm{N}]$,

I - moment of inertia of horizontal cross-section [m],

E -Young's modulus $\left[\mathrm{N} / \mathrm{m}^{2}\right]$.

The values of bending moments $\mathrm{M}_{i}, \mathrm{M}_{a}$ and reactions of joints $\mathrm{R}_{i}, \mathrm{R}_{a}$ were calculated from equations of the three moments and the formulae for elastic deformation of supports [5]. These calculations are time-consuming, although they are not very difficult, so will not be quoted hereby. The values of influence coefficients are presented in Table 3.

Values of influence coefficients, variant II

\begin{tabular}{|c|c|}
\hline$\delta^{\prime}{ }_{\mathbf{i j}}$ & Result [m/N] \\
\hline$\delta^{\prime}{ }_{11}$ & $1.174 \mathrm{E}-07$ \\
\hline$\delta^{\prime}{ }_{12}=\delta^{\prime}{ }_{21}$ & $6.866 \mathrm{E}-08$ \\
\hline$\delta^{\prime}{ }_{13}=\delta^{\prime}{ }_{31}$ & $1.591 \mathrm{E}-08$ \\
\hline$\delta^{\prime}{ }_{14}=\delta^{\prime}{ }_{41}$ & $-7.47 \mathrm{E}-09$ \\
\hline$\delta^{\prime}{ }_{22}$ & $1.06 \mathrm{E}-07$ \\
\hline$\delta^{\prime}{ }_{23}=\delta^{\prime}{ }_{32}$ & $5.91 \mathrm{E}-08$ \\
\hline$\delta^{\prime}{ }_{24}=\delta^{\prime}{ }_{42}$ & $-1.27 \mathrm{E}-09$ \\
\hline$\delta^{\prime}{ }_{33}$ & $9.539 \mathrm{E}-08$ \\
\hline$\delta^{\prime}{ }_{34}=\delta^{\prime}{ }_{43}$ & $3.025 \mathrm{E}-08$ \\
\hline$\delta^{\prime}{ }_{44}$ & $1.249 \mathrm{E}-07$ \\
\hline
\end{tabular}


After substituting the data, Eq. (4.3) takes the form:

$2,29048 \cdot 10^{-20} \cdot \omega^{8}-1,80605 \cdot 10^{-14} \cdot \omega^{6}+2,49 \cdot 10^{-09} \cdot \omega^{4}-0,000104 \cdot 10^{-05} \cdot \omega^{2}+1=0$.

Solving the equation for $\mathrm{f}$, we obtain the following four frequencies:

$$
\mathrm{f}_{1}=18.55 \mathrm{~Hz}, \quad \mathrm{f}_{2}=37.19 \mathrm{~Hz}, \quad \mathrm{f}_{3}=48.78 \mathrm{~Hz}, \quad \mathrm{f}_{4}=125.96 \mathrm{~Hz} .
$$

\section{Variant III}

Equations of motion for this variant are as follows:

$$
\begin{aligned}
& \delta_{11}^{\prime} m_{1} \ddot{y}_{1}+\delta_{12}^{\prime} m_{2} \ddot{y}_{2}+\delta_{13}^{\prime} m_{3} \ddot{y}_{3}+\delta_{14}^{\prime} m_{4} \ddot{y}_{4}+\delta_{11}^{\prime} c_{1} \dot{y}_{1}+\delta_{12}^{\prime} c_{2} \dot{y}_{2}+\delta_{13}^{\prime} c_{3} \dot{y}_{3}+\delta_{14}^{\prime} c_{4} \dot{y}_{4}+y_{1}=0 \\
& \delta_{21}^{\prime} m_{1} \ddot{y}_{1}+\delta_{22}^{\prime} m_{2} \ddot{y}_{2}+\delta_{23}^{\prime} m_{3} \ddot{y}_{3}+\delta_{24}^{\prime} m_{4} \ddot{y}_{4}+\delta_{21}^{\prime} c_{1} \dot{y}_{1}+\delta_{22}^{\prime} c_{2} \dot{y}_{2}+\delta_{23}^{\prime} c_{3} \dot{y}_{3}+\delta_{24}^{\prime} c_{4} \dot{y}_{4}+y_{2}=0 \\
& \delta_{31}^{\prime} m_{1} \ddot{y}_{1}+\delta_{32}^{\prime} m_{2} \ddot{y}_{2}+\delta_{33}^{\prime} m_{3} \ddot{y}_{3}+\delta_{34}^{\prime} m_{4} \ddot{y}_{4}+\delta_{31}^{\prime} c_{1} \dot{y}_{1}+\delta_{32}^{\prime} c_{2} \dot{y}_{2}+\delta_{33}^{\prime} c_{3} \dot{y}_{3}+\delta_{34}^{\prime} c_{4} \dot{y}_{4}+y_{3}=0 \\
& \delta_{41}^{\prime} m_{1} \ddot{y}_{1}+\delta_{42}^{\prime} m_{2} \ddot{y}_{2}+\delta_{43}^{\prime} m_{3} \ddot{y}_{3}+\delta_{44}^{\prime} m_{4} \ddot{y}_{4}+\delta_{41}^{\prime} c_{1} \dot{y}_{1}+\delta_{42}^{\prime} c_{2} \dot{y}_{2}+\delta_{43}^{\prime} c_{3} \dot{y}_{3}+\delta_{44}^{\prime} c_{4} \dot{y}_{4}+y_{4}=0 .
\end{aligned}
$$

They can be written in a matrix form as

$$
\Delta^{\prime} \mathbf{M} \ddot{Y}+\Delta^{\prime} \mathbf{C} \dot{Y}+\mathbf{E Y}=\mathbf{Q},
$$

where:

$\Delta^{\prime}=\left[\delta^{\prime}{ }_{\mathrm{ij}}\right]-$ coefficient matrix containing elasticity,

$\mathbf{M}$ - mass matrix,

C - damping matrix,

$\mathbf{E}$ - unit matrix,

Q - column matrix (null matrix).

The matrices $\mathrm{M}$ and $\mathrm{C}$ have the form:

$$
\begin{aligned}
\mathbf{M} & =\left[\begin{array}{cccc}
m_{1} & 0 & 0 & 0 \\
0 & m_{2} & 0 & 0 \\
0 & 0 & m_{3} & 0 \\
0 & 0 & 0 & m_{4}
\end{array}\right], \\
\mathbf{C} & =\left[\begin{array}{cccc}
c_{1} & 0 & 0 & 0 \\
0 & c_{2} & 0 & 0 \\
0 & 0 & c_{3} & 0 \\
0 & 0 & 0 & c_{4}
\end{array}\right]
\end{aligned}
$$

Assuming solution in the form of $\mathrm{y}(\mathrm{t})=\mathrm{Ae}^{i \omega t}$, after transformations we obtain:

$$
\operatorname{det}\left[\Delta^{\prime} \mathbf{M}\left(-\omega^{2}\right)+\Delta^{\prime} \mathbf{C}(\omega i)+\mathbf{E}\right]=0,
$$

whose determinant is a polynomial of $8^{\text {th }}$ degree: 
$A(\omega i)^{8}+B(\omega i)^{7}+C(\omega i)^{6}+D(\omega i)^{5}+E(\omega i)^{4}+F(\omega i)^{3}+G(\omega i)^{2}+H \omega i+I=W(\omega i)$,

where: coefficients A, B, C, D, E, F, G, H, I are real numbers. Solution to (4.14) consists of a real and an imaginary part:

$$
\begin{gathered}
A \omega^{8}-C \omega^{6}+E \omega^{4}-G \omega^{2}+I=\operatorname{Re}(\omega), \\
-B \omega^{7}+D \omega^{5}-F \omega^{3}+H \omega=\operatorname{Im}(\omega) .
\end{gathered}
$$

The solution can be presented in a graphical form, as an amplitude-phase frequency characteristics (Fig 8), or plots of real and imaginary parts versus $\omega$ (Fig. 9). From the latter, one can read the values of natural frequencies:

$$
\mathrm{f}_{1}=36.78 \mathrm{~Hz}, \quad \mathrm{f}_{2}=48.86 \mathrm{~Hz}, \quad \mathrm{f}_{3}=110.68 \mathrm{~Hz}, \quad \mathrm{f}_{4}=126.08 \mathrm{~Hz} .
$$

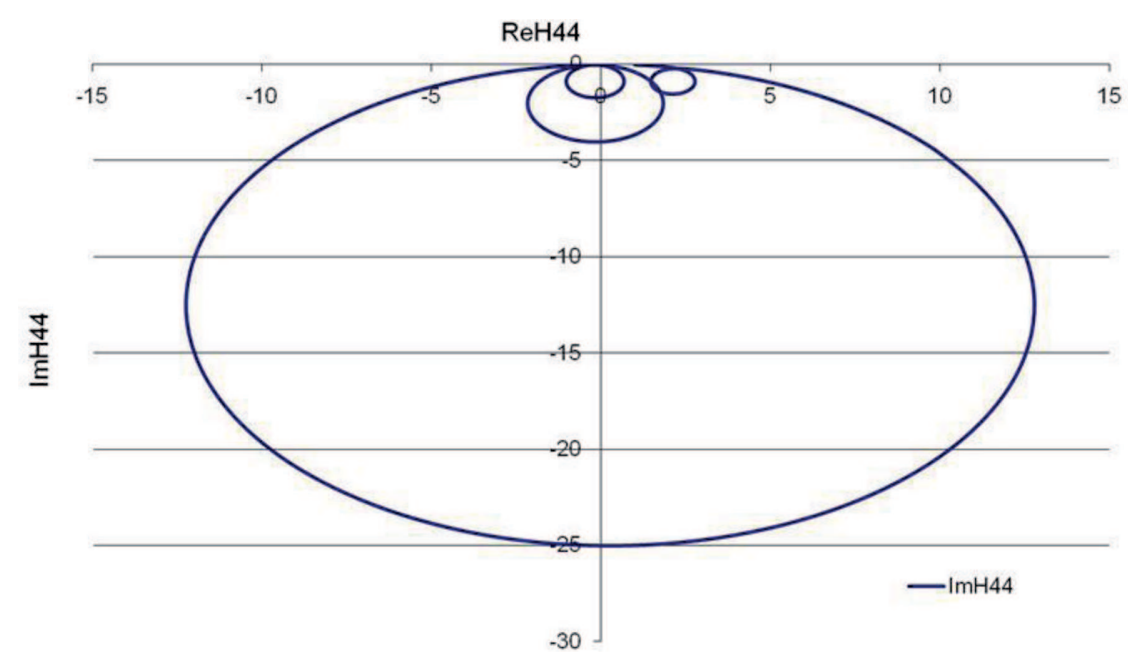

Fig. 8. The amplitude-phase frequency characteristics

\section{Numerical calculations, comparison of results}

In order to verify correctness of solutions obtained with analytical method, we performed numerical calculations. The comparisons were made for the beam from variant I. For numerical calculations, the MSC.Adams software was used.

Figure 10 presents forms of vibrations of the section of the beam with rotors, and the vibration frequencies calculated with MSC.Adams. 


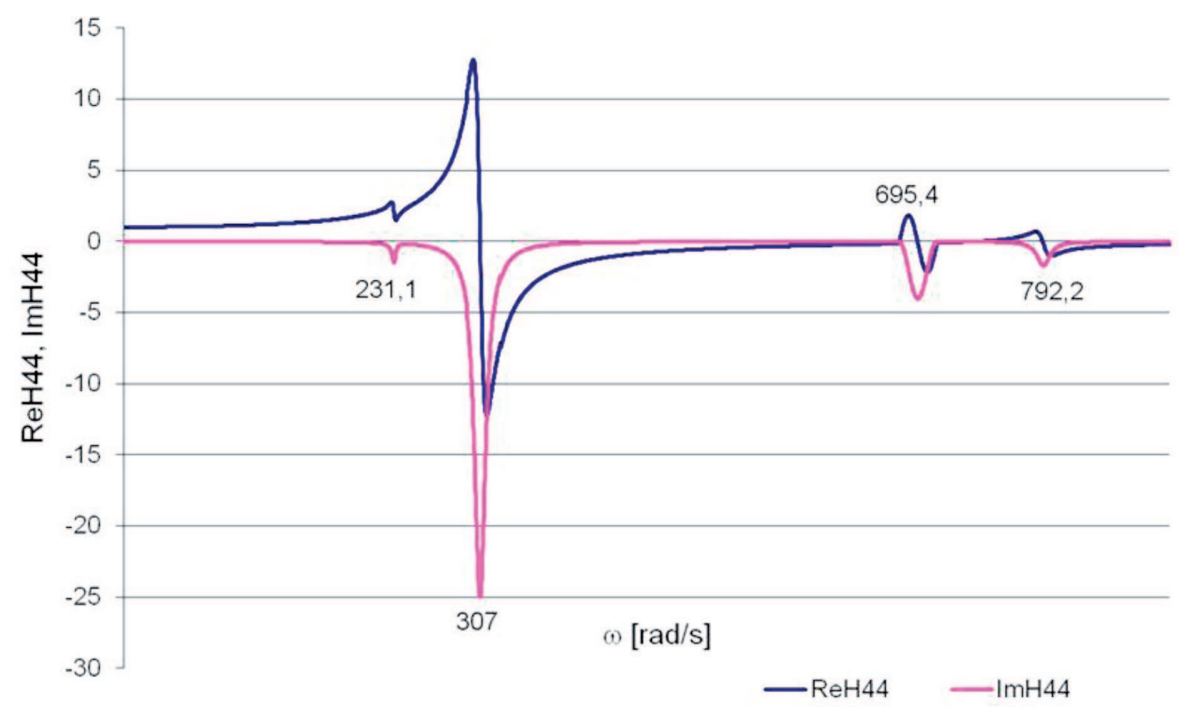

Fig. 9. Real and imaginary parts of solution in the function of $\omega$
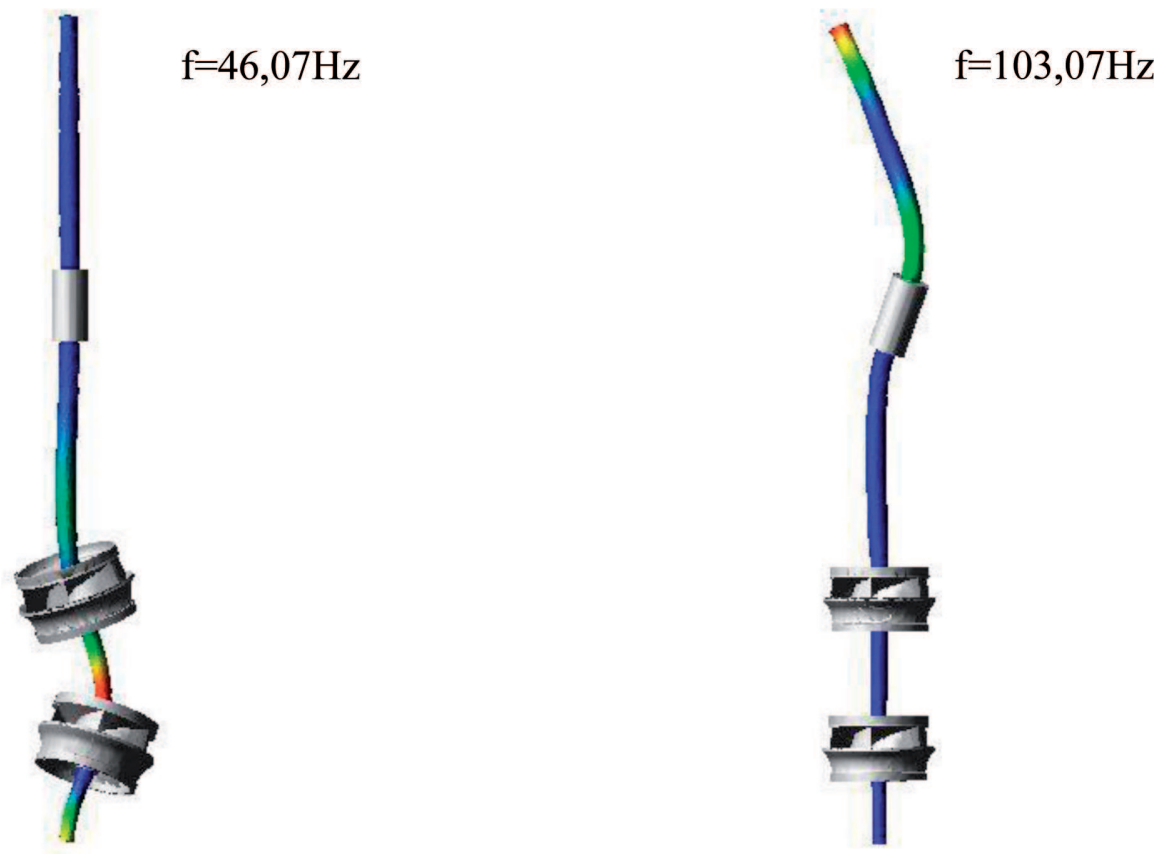


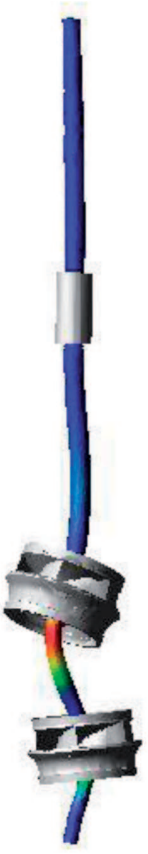

$$
\mathrm{f}=163,17 \mathrm{~Hz}
$$

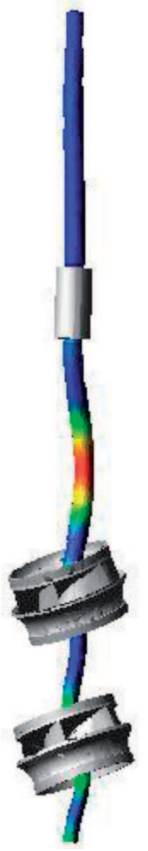

$\mathrm{f}=226,75 \mathrm{~Hz}$

Fig. 10. Results of numerical analysis with MSC.Adams software

A juxtaposition of all calculations of bending vibrations of the shaft for different variants of the shaft's support are presented in Table 4.

Table 4.

Comparison of calculation results for shaft frequency for three variants of supports

\begin{tabular}{|c|c|c|c|c|}
\hline & \multicolumn{2}{|c|}{ Shaft on rigid supports } & $\begin{array}{c}\text { Shaft on elastic } \\
\text { supports }\end{array}$ & $\begin{array}{c}\text { Shaft on } \\
\text { supports of } \\
\text { rigidity k and } \\
\text { damping c }\end{array}$ \\
\cline { 2 - 5 } & $\begin{array}{c}\text { Analytical } \\
\text { calculations }\end{array}$ & $\begin{array}{c}\text { ADAMS } \\
\text { software }\end{array}$ & $\begin{array}{c}\text { Analytical } \\
\text { calculations }\end{array}$ & $\begin{array}{c}\text { Analytical } \\
\text { calculations }\end{array}$ \\
\hline $\mathrm{f}_{1}[\mathrm{~Hz}]$ & 40.63 & 46.07 & 18.55 & 36.78 \\
\hline $\mathrm{f}_{2}[\mathrm{~Hz}]$ & 82.67 & 103.07 & 37.19 & 48.86 \\
\hline $\mathrm{f}_{3}[\mathrm{~Hz}]$ & 126.84 & 163.17 & 88.78 & 110.68 \\
\hline $\mathrm{f}_{4}[\mathrm{~Hz}]$ & 264.73 & 226.75 & 125.96 & 126.08 \\
\hline
\end{tabular}

\section{Conclusions}

1. Comparison of numerical calculations with analytical results for variant I showed that both methods of calculations were correct. Differences between calculations resulted from the fact that the mathematical model did 
not take into account moments of inertia of the rotating masses, and neglected variable rigidity of the shaft. The applied simplifications of numerical model could also lead to discrepancies.

2. Numerical calculations are much faster, however, analytical calculations provide information about the form of mutual relations between parameters.

3. Having analytical solutions, one can, in the next step, carry out calculation to determine system sensitivity to individual parameters. In particular, one can evaluate the influence of support arrangement.

4. It is noticeable that, after taking into account damping in the supports, one observes significant increase of frequency of vibrations.

Manuscript received by Editorial Board, September 18, 2012;

final version, June 25, 2013.

\section{REFERENCES}

[1] Gryboś R.: Drgania maszyn, Wydawnictwo Politechniki Śląskiej, Gliwice 2009.

[2] Adiletta G., Guido A.R., Rossi C.: Nonlinear dynamics of a rigid unbalanced rotor in journal bearings. Part II: Experimental analysis, Nonlinear Dynamics, 14, 157-189 1997.

[3] Alnefale K.: Shaft mass effect on the dynamic behaviour of a rotor supported by fluid film bearings, Proceedings of the Institution of Mechanical Engineers, Part C: Journal of Mechanical Engineering Science, 222, 643-651, 2008.

[4] Avramov K.V.: Vibrations of a single-disk rotor on nonlinear supports, International Applied Mechanics, 45, 10, 1112-1119, 2009.

[5] Dyląg Z., Krzemińska-Niemiec E., Filip F.: Mechanika budowli. T.1, PWN, Warszawa 1980.

Modelowanie pionowego wału pompy diagonalnej

Streszczenie

Celem pracy jest modelowanie wału dużej pionowej pompy diagonalnej, o długości całkowitej: l=4866mm oraz obliczenie częstości drgań własnych i obrotów krytycznych. Wyznaczono analitycznie równania ruchu a następnie sprawdzono uzyskane rezultaty obliczeń za pomocą modelowania numerycznego. Utrudnienie pracy stanowiło ułożyskowanie wału w czterech łożyskach hydrodynamicznych o nieznanych parametrach. Jako model dyskretny wału przyjęto belkę czteromasową podpartą na podatnych podporach o sztywności k i tłumieniu c. Równania ruchu układu wyprowadzono metodą sił. W celu zweryfikowania poprawności wyprowadzonych równań rozważano modele belek w trzech etapach różniących się konfiguracją podparcia: belka podparta na sztywnych podporach, belka podparta na podporach sprężystych, belka podparta na podporach podatnych o sztywności k i tłumieniu c. Rezultaty obliczeń podano w tabelach i na wykresach. 